\title{
The Intracrine Renin-Angiotensin System
}

\author{
Rajesh Kumar, Candice M. Thomas, Qian Chen Yong, Wen Chen, and Kenneth M. Baker \\ Division of Molecular Cardiology, Department of Medicine, Texas A\&M Health Science Center, \\ College of Medicine; Scott \& White; Central Texas Veterans Health Care System, Temple, TX
}

\section{Abstract}

The renin-angiotensin system (RAS) is one of the earliest and most extensively studied hormonal systems. The RAS is an atypical hormonal system in several ways. The major bioactive peptide of the system, angiotensin (Ang) II, is neither synthesized in, nor targets one specific organ. New research has identified additional peptides with important physiological and pathological roles. More peptides also mean newer enzymatic cascades that generate these peptides and more receptors that mediate the function. In addition, completely different roles of components that constitute the RAS have been uncovered, such as that for prorenin via the prorenin receptor. Complexity of the RAS is further enhanced by the presence of sub-systems in tissues, which act in an autocrine/paracrine manner independent of the endocrine system. The RAS seems relevant at the cellular level, wherein individual cells have a complete system, termed the intracellular RAS. Thus, from cells to tissues to the entire organism, the RAS exhibits continuity while maintaining independent control at different levels. The intracellular RAS is a relatively new concept for the RAS. The current review presents a synopsis of the literature on this system in different tissues.

\section{Introduction}

The renin-angiotensin system (RAS) is one of the most significant and extensively studied hormonal systems in humans. Beginning with the discovery in 1898 by Tigerstedt and Bergman of a factor released from kidneys that controlled blood pressure, the RAS has expanded into an extensive system of enzymatic cascades, bioactive molecules, and multiple receptors $(1,2)$. Consequently, this system has pleiotropic effects which control functions at multiple levels, from cells to tissues to the entire organism. Thus, it is not surprising that this system is regulated at each level independently and in concert with others, to fine tune the desired outcome. It is important to elucidate the RAS at every level to completely understand the interplay and mechanisms by which it regulates bodily functions.

In the simplest form, the RAS encompasses sequential conversion of angiotensinogen (AGT) by renin and angiotensin converting enzyme (ACE) into angiotensin (Ang) I and Ang II, respectively. Ang II binds to two specific and ubiquitous G-protein coupled receptors, Ang receptor type $\mathrm{I}\left(\mathrm{AT}_{1}\right)$ and type II $\left(\mathrm{AT}_{2}\right)$, to carry out biological functions. However, the RAS is significantly more complex. To deal with the complexity, the RAS will be divided into subsystems based on two parameters: i) new versus old knowledge and, ii) the site of synthesis and actions of Ang II.

Based on traditional versus new knowledge, the RAS can be categorized as the classical and the novel RAS (Fig. 1). The former is the simplest form of the RAS described above. This consists of a single bioactive peptide Ang II and two specific receptors $\mathrm{AT}_{1}$ and $\mathrm{AT}_{2}$. The 
physiological function of the classical RAS is to maintain vascular tone through direct effects on vascular smooth muscle cells and salt and water homeostasis through aldosterone secretion (3). The novel RAS includes several new bioactive peptide products, their receptors, and newly identified activities of previously inert components. Among new Ang peptides, Ang 1-7, Ang III, and Ang IV are notable, with significant biological activity via binding to Mas, $\mathrm{AT}_{1}$ and $\mathrm{AT}_{2}$, and insulin regulated aminopeptidase (IRAP), respectively. Interestingly, Ang 1-7 actions are opposite to those of Ang II (4). Ang IV has an independent profile of biological actions, which include memory formation and control of water intake (5). In addition to these new Ang peptides, prorenin and renin have been assigned new biological roles that are independent of Ang II production. Both prorenin and renin bind to a specific receptor, the (pro)renin receptor (PRR) and initiate intracellular signaling pathways that include MAPK and Wnt (6). The novel RAS represents a dramatic expansion of the classical RAS, in terms of both the number of active molecules and biological functions.

Using the second parameter of the site of synthesis and actions, the RAS can be classified into systemic/circulating, local/tissue, and intracellular systems (Fig. 2). At the systemic level, Ang II is formed in the circulation from AGT secreted from liver, renin from kidneys, and ACE located on vascular endothelial cells. Actions of circulation-derived Ang II on the vascular wall and elsewhere in tissues are termed endocrine functions. The local or tissue RAS is defined by synthesis of Ang II within tissues, from AGT and enzymes produced locally (7). The local RAS may utilize enzymes other than renin and ACE for the synthesis of Ang II, such as cathepsins and chymase $(8,9)$. Since AGT is a secretory protein, synthesis of Ang II is thought to occur largely in the interstitial space. Newly synthesized Ang II acts on neighboring cells and these actions of Ang II are termed autocrine/paracrine effects. The function and regulation of the tissue RAS is independent of the circulating system (10). The intracellular RAS is characterized by synthesis and actions of Ang II within a cell (11). The actions of Ang II that are initiated inside the cell are termed intracrine effects. Intracrine effects may also be produced by Ang II that is internalized from the interstitial space. The intracellular RAS is one of the newest concepts in the area of studies related to the RAS; thus, is a subject of considerable discussion and debate (12). The nature of the intracellular RAS in different cell types and pathophysiological significance has not been thoroughly investigated. However, recent studies have suggested that the intracellular RAS provides another dimension to RAS regulation and function in tissues. There is evidence that in some cell types and pathological conditions, the intracellular RAS may have a predominant role $(13,14)$. The circulating and tissue RASs have been reviewed by other investigators in this themed series issue. In this article, we focus on the presence and composition of the intracellular RAS and intracrine function of Ang II in different tissues.

\section{Intracrine Actions of Ang II: Prelude to the Intracellular RAS}

Intracrine actions of Ang II are those that are initiated from an intracellular location, rather than by binding to plasma membrane $\mathrm{AT}_{1}$ or $\mathrm{AT}_{2}$ receptors. The concept of intracrine actions of Ang II began with the observation that when labeled Ang II was injected into the left ventricle of adult rats, it localized to the nuclear zone of vascular and cardiac muscle cells (15). Later studies confirmed that Ang II can bind to isolated nuclei and chromatin, resulting in a change in gene expression (16-18). Others and we discovered that nuclear Ang II binding sites on hepatocytes were $\mathrm{AT}_{1}$-like, further strengthening the concept of intracrine functionality of Ang II $(19,20)$. More systemic studies were subsequently performed in different cell types to establish the intracrine nature of Ang II, as detailed below. 


\section{The intracrine RAS in cardiac myocytes and fibroblasts}

Direct effects of intracellular Ang II in intact cells were first reported on cellular communication in cardiac myocytes. Intracellular dialysis of Ang II caused a decrease in junctional conductance in isolated cell pairs of rat cardiac myocytes (21). These effects of Ang II were blocked by intracellular administration of losartan, suggesting involvement of an intracellular $\mathrm{AT}_{1}$-like receptor. A similar decrease in junctional conductance was observed following dialysis of renin or renin plus AGT in cardiac myocyte cell pairs (22). The observation that these effects were prevented by a renin or ACE inhibitor, suggested that intracellular Ang II was involved. To further confirm that endogenous intracellular Ang II influences cell communication in the failing heart, isolated cell pairs from failing hearts of cardiomyopathic hamsters (at 2 and at 6 months of age) were studied (23). In this model, signs of heart failure were not evident and activity of the RAS was low at 2 months, compared to 6 months. Both Ang I and Ang II decreased junctional conductance in cell pairs from 2 month old hamsters, while causing cell uncoupling in cell pairs from 6 month old animals. In separate experiments, ACE inhibitors and an ARB alone did not produce any effect on cell coupling at 2 months of age, while increasing it at 6 months. These effects correlated with activity of the RAS at these stages of heart failure, suggesting a role of endogenous Ang II in cell communication in the failing heart (23). Additionally, intracellular administration of Ang II increased the peak inward calcium current density in cardiac myocytes isolated from cardiomyopathic hamsters (24), which was inhibited by the mineralocorticoid receptor antagonist eplerenone (25). The latter reduced the expression of plasma membrane and intracellular $\mathrm{AT}_{1}$ receptor, which might have contributed to the observed effects.

We studied the effect of intracellular Ang II on cardiac myocyte cell growth and cardiac hypertrophy. Intracellular Ang II was produced in cardiac myocytes using a recombinant adenovirus, coding for Ang II peptide without a signal sequence. This approach resulted in increased Ang II levels in cell lysates; but, not in culture medium. Neonatal rat ventricular myocytes (NRVM), infected with the adenoviral vector, showed significant hypertrophic growth as determined by cell size, protein synthesis and enhanced cytoskeletal rearrangement (26). Adult mice, injected with a similar intracellular Ang II coding plasmid vector, developed significant cardiac hypertrophy, without an associated increase in blood pressure or plasma Ang II levels. Losartan did not block the growth effects, excluding involvement of extracellular Ang II and the plasma membrane AT1 receptor (26). However, the latter observation suggested that Ang II interacts with intracellular proteins other than the $\mathrm{AT}_{1}$ receptor. Our later studies identified high ambient glucose as a potent stimulus for endogenous intracellular Ang II production in cultured cardiac myocytes and fibroblasts (14, 27). We observed that endogenous intracellular Ang II stimulated expression of AGT in cardiac myocytes and was involved in increased TGF- $\beta$ and collagen expression by cardiac fibroblasts, when exposed to high glucose $(14,27)$.

In a recent study, Ang II microinjected into isolated adult rat cardiac myocytes was localized to the perinuclear and nuclear region (28). Exposure of isolated nuclei obtained from cardiac myocytes to Ang II resulted in enhanced de novo RNA synthesis, specifically NF- $\kappa \mathrm{B}$ mRNA expression. Ang-II applied to purified nuclei versus intact cardiac myocytes, showed a greater increase in NF- $\kappa \mathrm{B}$ mRNA levels following nuclear application, suggesting preferential nuclear signaling.

Most effects of intracellular Ang II are similar to that of extracellular Ang II. However, it was reported that while extracellular Ang II increased cell volume of cardiac myocytes isolated from cardiomyopathic hamsters, intracellular Ang II reduced it (29). Interestingly, aldosterone enhanced the effects of both extracellular and intracellular Ang II, partly due to the effect on $\mathrm{AT}_{1}$ expression (30). It was proposed that intracellular Ang II might have a 
protective role, in conditions such as myocardial ischemia, by reducing cell volume $(7,31)$. Together, these studies demonstrate intracrine functionality of Ang II in cardiac cells, both in vitro and in vivo, by artificially delivered, recombinant, and endogenous intracellular Ang II.

\section{Intracrine Ang II in vascular smooth muscle cells (VSMCs)}

In VSMCs, Ang II was localized in endosomes and nuclei following microinjection. This was accompanied by a rapid increase in intracellular calcium $([\mathrm{Ca} 2+] \mathrm{i})$ in the cytosol and nucleus due to the influx of extracellular $\mathrm{Ca} 2+$ ions. The increase in [Ca2+]i was also observed in adjacent cells; however, that increase was due to $\mathrm{Ca} 2+$ release from intracellular stores. These effects were blocked by intracellular, but not extracellular application of candesartan, suggesting involvement of an intracellular $\mathrm{AT}_{1}$-like receptor (32). When delivered intracellularly in de-endothelized rat aorta rings using liposomes, Ang II caused a dose-dependent contraction, which was dependent on $\mathrm{Ca} 2+$ influx from the medium, not on inositol-1,4,5-trisphosphate (Ins(1,4,5)P3) mediated release from intracellular Ca2+-stores, similar to that observed in the previous study. These effects of intracellular Ang II were sensitive to intracellular, but not extracellular administration of candesartan (33). In A7r5 VSMCs, which are devoid of extracellular Ang II effects, intracellular administration of Ang II through liposomes or cell permeabilization, resulted in enhanced Ca2+ influx, DNA synthesis, and cell proliferation. Additionally, intracellular Ang II modulated Ca2+ influx caused by serotonin receptor stimulation in these cells. Using various $\mathrm{AT}_{1}$ and $\mathrm{AT}_{2}$ receptor antagonists, the effects of intracellular Ang II in A7r5 VSMCs were ascribed to two distinct, low and high affinity, binding sites (34-37). In the rat VSMC cell line A10, transfection with intracellular Ang II and $\mathrm{AT}_{1}$ receptor expression vectors, resulted in enhanced cell proliferation, which was mechanistically linked to p38MAPK and cAMP response elementbinding protein (CREB) activation (38).

\section{Intracrine Ang II in kidney cells}

Renal proximal tubule cells (PTCs) grown in high glucose medium, showed elevated intracellular Ang II levels that were associated with increased N-Acetyl-betaglucosaminidase secretion and p22phox protein levels, which were normalized by treatment with different ARBs, suggesting the involvement of intracellular Ang II in mediating high glucose effects (39). Microinjection of Ang II into single PTCs elicited a marked increase in cytoplasmic [Ca2+]i, likely from intracellular $\mathrm{Ca} 2+$ stores (40). These effects were blocked by intracellular, but not extracellular application of losartan, an observation similar to that described for VSMCs.

\section{Intracrine Ang II in other cell types}

Using a recombinant DNA approach, a mutated AGT lacking the secretory signal, was expressed in rat hepatoma cells that also produced renin and ACE. These cells demonstrated an increased mitotic index and PDGF expression, which was blocked by a renin antisense oligonucleotide and losartan, but not by candesartan. The latter is less lipophilic than losartan, and thus likely did not enter cells in a sufficient amount to block the intracellular $\mathrm{AT}_{1}$ receptor (41). Co-expression of Ang II and $\mathrm{AT}_{1}$ in COS-7 and CHO-K1 cells significantly enhanced cell proliferation, compared to expression of any single protein (42). The increase in cell proliferation was prevented by losartan, but not anti-Ang II antibody added to the culture medium, excluding the possibility of extracellular Ang II effects. Significantly, co-expression of intracellular Ang II with $\mathrm{AT}_{1}$ receptor resulted in increased localization of the latter to the nucleus, which was associated with CREB activation. Studies in our laboratory demonstrated that when Ang II was overexpressed as a native peptide, without fusion to a fluorescent protein, a significant increase in cell proliferation was 
observed in CHO-K1 cells in the absence of functional $\mathrm{AT}_{1}$ receptors (43). These studies corroborated the lack of effect of ARBs on intracellular Ang II-mediated cardiac myocyte cell growth and cardiac hypertrophy, suggesting novel $\mathrm{AT}_{1}$-independent effects of intracellular Ang II in the absence of $\mathrm{AT}_{1}$ receptor. In rat luteal cells, Ang II was shown to be localized to the cytoplasm and nucleus by confocal microscopy. Losartan inhibited progesterone production in permeabilized, but not intact luteal cells, which was reversed by Ang II, suggesting that Ang II modulated steroidogenesis through intracellular AT1 receptors (44).

\section{Intracrine Ang II in vivo}

A direct demonstration of intracrine effects of Ang II in an animal model had not been possible due to difficulty in separating intracellular Ang II effects from those initiated at the plasma membrane. However, an association of intracellular Ang II levels with the pathological state has been demonstrated in both human and animal studies. Increased intracellular Ang II staining was observed in myocardium from diabetic patients, which also showed increased apoptosis, necrosis, and oxidative stress, compared to non-diabetic controls (45). Intracellular Ang II levels were shown to be further increased in hypertensive diabetic patients, suggesting an association with disease severity, as determined by cardiac hypertrophy, cavity dilation, and depressed ventricular performance (45). Interestingly, the study patients were on ACE inhibitor therapy, which corroborated our in vitro studies in cardiac myocytes, of chymase-mediated Ang II generation following exposure to high glucose (14). Similarly, our in vivo animal studies demonstrated that increased intracellular Ang II in diabetic rat heart was associated with enhanced cardiac myocyte apoptosis, fibrosis, and oxidative stress. The latter conditions were alleviated better by a renin inhibitor, which blocks the intracellular RAS, compared to an ARB and ACE inhibitor (13).

Recently, a transgenic mouse line was generated, that expressed Ang II fused downstream of a cyan fluorescent protein without a secretory signal (46). The transgene expression was observed in multiple tissues, without an associated increase in circulating Ang II levels, compared to controls. These animals were hypertensive and showed thrombotic microangiopathy in glomerular capillaries and small vessels. These studies were the first direct demonstration that an intracellular fluorescent fusion protein of Ang II caused elevated blood pressure and kidney pathology in mice (46). In another study, a similar adenoviral construct of intracellular Ang II was expressed in the superficial cortex of rat and mouse kidneys, under a sodium and glucose cotransporter-2 promoter (47). These animals demonstrated an increase in systolic blood pressure $(28 \mathrm{mmHg})$ and decrease in sodium and lithium excretion by $20-24 \%$. The effects of intracellular Ang II were blocked by losartan in wild type animals and prevented in $\mathrm{AT}_{1 \mathrm{a}}-\mathrm{KO}$ mice, suggesting a requirement of intracellular $\mathrm{AT}_{1}$ receptors in the kidneys.

\section{The Intracellular RAS: Concept and Controversies}

As alluded to earlier, the intracellular RAS is defined by the presence of RAS components and synthesis and actions of Ang II, and possibly other active Ang peptides, within a cell. Though conceptually simple, the presence of such a system was difficult to reconcile in view of the evolution of our knowledge regarding the RAS (48). In the 1930s, Ang II was originally identified as hypertensin/angiotonin that was released in the plasma from ischemic kidneys. Later studies revealed that kidneys produced an enzyme that acted on a substrate in plasma, which were identified as renin and AGT, respectively. ACE, which converts Ang I to Ang II, was discovered in 1956 and the concept of the classical RAS originated (48). AGT, the only known precursor of Ang II, is a secretory protein. Renin is also a secretory protein expressed as the inactive precursor prorenin and only renal juxtaglomerular cells appear to have the capacity to convert it into active renin. Another component of the RAS, 
ACE, is a membrane bound enzyme with catalytic sites located on the extracellular domain. Furthermore, Ang II receptors are G-protein coupled plasma membrane receptors. In view of the evolutionary history and the nature of individual components, the concept of the RAS as a circulating and extracellular system is preeminent in our thinking. Thus, intracellular synthesis of Ang II seemed less plausible and was not explored until intracrine effects of Ang II were identified.

To describe an intracellular RAS, two possible characteristics of the system were considered (11). One of these was intracellular RAS as a transient system present in secretory vesicles. Being secretory proteins of a single system, it was hypothesized that renin, AGT, and ACE were co-sorted in secretory vesicles, resulting in Ang II generation due to close proximity of the components. A portion of the newly generated Ang II could move into the cytoplasm and the remaining, secreted through constitutive or regulated pathways. There is evidence of co-localization of different RAS components in the same secretory vesicles of different cell types. Electron microscopic immunohistochemistry in neonatal and adult rat kidney sections, showed co-localization of renin, Ang I, and Ang II in cytoplasmic granules of juxtaglomerular cells (49). AGT was distributed throughout the cytoplasm. Using a reverse hemolytic plaque assay, release of Ang I and renin from individual renocortical cells was demonstrated, suggesting intracellular generation of Ang I (49). It was reported that the presence of large amounts of Ang II in the storage granules (that contained renin) of renal juxtaglomerular cells was due to intracellular synthesis, likely following uptake of exogenous AGT $(50,51)$. The subcellular fractionation of renin granules from kidney homogenate, further demonstrated the presence of Ang I and Ang II in renin granule fractions (51). In rat anterior pituitary, AGT, prorenin, and renin were co-localized in the same secretory vesicles in all glandular cell types, using immunoelectron microscopy, suggesting intragranular processing of these components. These studies further suggested sorting of RAS components into a regulated, in addition to constitutive, secretory pathway (52). The observation of release of Ang II by cardiac myocytes cultured in serum-free medium, following mechanical stretch, also supported intracellular generation and regulated secretion $(53,54)$.

The second characteristic of the intracellular RAS was an intracellular system present in non-secretory cellular compartments, either in the cytoplasm, nucleus, mitochondria, and/or other cellular organelles. The precise cellular trafficking of RAS components in different cell types and pathological conditions is not known. Different isoforms of RAS components, formed as a result of post-translational modifications or alternative transcription or posttranscription processing of mRNA, might traffic to intracellular locations other than secretory vesicles. A human astrocyte cell line was reported to express primarily the nonglycosylated form of AGT, which was localized to the nucleus (55). Similarly, primary cultures of glial cells, isolated from transgenic mice expressing human AGT, showed nuclear localization (55). Using fusion constructs of human AGT fragments with green fluorescent protein, a nuclear localization signal was demonstrated at the C-terminus of AGT (55). With regard to renin, three human and two rat renin mRNA isoforms, resulting from alternative transcription or splicing, have been described $(56,57)$. These different renin mRNA species, translate into two renin protein isoforms. One is the classical secretory renin, whereas the second isoform lacks the pre-pro-fragment and is intracellular. The expression of renin isoforms is tissue specific; intracellular isoforms being expressed in the adrenal gland, brain and heart $(58,59)$. In transgenic animals, intracellular renin enhanced aldosterone production in rats and increased blood pressure and drinking volume when overexpressed in the mouse brain $(60,61)$. Cytosolic renin, when overexpressed in H9c2 cardiomyoblasts, was localized in mitochondria, resulting in enhanced apoptosis (62). Similar to AGT and renin, ACE and its fragments have been shown to be localized in intracellular compartments, including the nucleus, in mesangial, smooth muscle, and 
endothelial cells $(63,64)$. Together, these studies support the concept of a functionally relevant intracellular RAS in several cell types. In the following section, we will review the literature demonstrating intracellular synthesis of Ang II.

\section{The cardiac intracellular RAS}

Cardiac cells constitutively express most components of the RAS, with the exception of renin, the expression of which is more often associated with pathological conditions (65, 66). That these endogenous components constitute an intracellular system has been suggested by functional studies or directly demonstrated by de novo intracellular Ang II synthesis. As discussed above, intracellular Ang II has effects on cellular communication in cardiac myocytes. The effect of dialysis of Ang I on junctional conductance in cardiac myocyte cell pairs was abolished by an ACE inhibitor (21). Similarly, intracellular dialysis of renin reduced junctional conductance, which was reversed by a renin inhibitor and enalaprilat, suggesting intracellular conversion of Ang I to Ang II (22). In rat aortic rings, intracellular administration of Ang I caused contraction similar to Ang II, which was abolished by candesartan, but not by captopril, suggesting Ang II-mediated effects through intracellular Ang II generation independent of ACE (33). In a study on isolated perfused rat hearts overexpressing human AGT, perfusion with renin caused a sustained increase in Ang II formation, even after renin was no longer detectable in the perfusate; whereas, Ang I perfusion caused increased Ang II levels only during the perfusion period (67). These studies suggest that renin is taken up by cardiac cells, resulting in sustained intracellular Ang II generation.

In a more direct demonstration of intracellular Ang II synthesis, NRVM were incubated in serum-free medium and exposed to isoproterenol or high glucose in the presence of candesartan (14). The latter was used to prevent $\mathrm{AT}_{1}$-mediated internalization of Ang II. Ang II was measured in cell lysates and the culture medium, which represented intra- and extracellularly synthesized Ang II, respectively. Isoproterenol increased the Ang II concentration in both the cell lysate and culture medium, whereas high glucose markedly increased Ang II synthesis only in the cell lysate of NRVM. Western analysis revealed increased intracellular levels of AGT, renin, and chymase in high-glucose-exposed cells. Confocal immunofluorocytometry confirmed the presence of Ang II in the cytoplasm and nucleus of high-glucose-exposed NRVM and along the actin filaments in isoproterenolexposed cells. The results of the immunostaining experiments suggested that Ang II synthesis occurred in the secretory pathway in response to isoproterenol and in nonsecretory locations in response to high glucose. Consistent with the latter conclusion, is that Ang II synthesis was dependent on renin and chymase in high-glucose-exposed cells and on renin and ACE in isoproterenol-exposed cells (14). Similarly, high glucose-induced intracellular Ang II synthesis was observed in adult mouse cardiac myocytes (68). However, in cardiac fibroblasts, intracellular Ang II synthesis appeared to occur only in the secretory pathway mediated through the actions of renin and ACE, following both isoproterenol and high glucose stimulation (27). In summary, the site of Ang II synthesis, intracellular localization, and synthetic pathways were dependent on the stimulus and cell type. Significantly, NRVM synthesized and retained Ang II intracellularly, which redistributed to the nucleus under high-glucose conditions, suggesting a role for an intracrine mechanism in diabetic conditions.

Cardiac intracellular Ang II synthesis was also suggested by animal studies. One week of diabetes in rats, resulted in significantly increased intracellular Ang II levels in cardiac myocytes, which were not normalized by candesartan, suggesting that Ang II was synthesized intracellularly, not internalized through $\mathrm{AT}_{1}$ receptor (13). Increased intracellular levels of Ang II, AGT, and renin were observed by confocal microscopy. 
Intracellular Ang II synthesis was blocked by aliskiren, but not by benazepril, findings which were consistent with in vitro studies. Diabetes-induced superoxide production and cardiac fibrosis were partially inhibited by candesartan and benazepril, whereas aliskiren produced complete inhibition, suggesting a link with intracellular Ang II (13).

In addition to intracellular Ang II synthesis, both $\mathrm{AT}_{1}$ and $\mathrm{AT}_{2}$ receptors were detected in nucleus-enriched fractions from isolated adult rat cardiac myocytes by Western analysis (28). These receptors were localized on nuclear membranes by confocal microscopy and were demonstrated to functionally couple to signaling, as was evident from increased nuclear $[\mathrm{Ca} 2+]$ levels and NF- $\kappa \mathrm{B}$ expression, following exposure of isolated nuclei to Ang II (28). Recently, $\mathrm{AT}_{1}$ and $\mathrm{AT}_{2}$ receptors were also detected in mitochondria from human monocytes, mouse hepatocytes, kidney tubular cells, neurons, and cardiac myocytes by immune-electron microscopy (69). Significantly, $\mathrm{AT}_{2}$ receptor colocalized with endogenous Ang II/III and modulated nitric oxide production and mitochondrial respiration (69). The origin of intracellular Ang II receptors is not clear, and could be due to direct trafficking of newly formed receptors to different intracellular locations or internalization following stimulation with Ang II. Though there is no direct evidence for the former, the latter has been extensively studied (42, 70-72). In summary, a complete intracellular system for Ang II synthesis and actions, including signaling mechanisms and cellular effects has been described in the heart (68).

\section{The renal intracellular RAS}

Human mesangial cells grown in high glucose medium showed increased levels of Ang II in the cell lysate, but not in the culture medium. The observed increase in Ang II was blocked by chymostatin, but not captopril, and was associated with a 3-fold increase in chymase mRNA levels. Significantly, blocking $\mathrm{AT}_{1}$ receptor by losartan did not affect intracellular Ang II levels, suggesting intracellular generation, not uptake of Ang II in these cells (73). A significant amount of Ang II induced by high glucose in a mouse mesangial cell line was localized to the nucleus (74). It was demonstrated that high glucose induced increased expression of prorenin at early time points, reduced prorenin secretion, and increased the rate of prorenin to renin conversion, resulting in increased intracellular Ang II generation in mesangial cells (75). Similarly, other investigators reported chymase-mediated intracellular Ang II synthesis in rat mesangial cells in response to high glucose (76). Significantly, it was reported in patients that normal kidneys weakly expressed chymase in mesangial and VSMCs; however, there was a 10-15-fold increase in chymase expression in the diabetic kidney (77). Chymase expression further increased 4-7-fold in hypertensive patients compared to normotensives, a finding which correlated with the increase in blood pressure and the severity of collagen matrix deposition, in contrast to ACE expression (77).

Immortalized human podocytes were shown to contain intracellular Ang II, levels of which were significantly increased following exposure to prorenin (78). Prorenin-induced intracellular Ang II levels were reduced by an ACE and renin inhibitor, but not by an ARB. The latter observation suggested that Ang II was formed intracellularly in human podocytes and not internalized through $\mathrm{AT}_{1}$ receptor. How prorenin was internalized, activated, and interacted with AGT in podocytes was not clear. However, siRNA induced downregulation of the PRR, attenuated prorenin-induced intracellular Ang II generation, suggesting that the PRR was an important component of the intracellular Ang II synthesis machinery in human podocytes (78). A significant role of the PRR in diabetic kidney diseases has previously been demonstrated (79-81). Similarly, high glucose increased renin-mediated intracellular Ang II levels in cultured podocytes $(82,83)$.

Recently, significant levels of $\mathrm{AT}_{1}$ receptor were demonstrated on nuclei isolated from rat and sheep kidneys $(84,85)$. Importantly, renal cortical nuclei exhibited higher $\mathrm{AT}_{1}$ sites, in 
comparison to the plasma membrane, while receptor density was similar in the medulla, in Lewis rats (84). In sheep, nuclei isolated from kidneys of young adult animals showed $\mathrm{AT}_{2}$ as the predominant receptor (80\%), whereas $\mathrm{AT}_{1}$ accounted for the majority (about $85 \%$ ) of Ang II binding sites in older sheep (85). Mas protein, the Ang 1-7 receptor, was also detected on sheep renal nuclei by immunoblotting (85). Thus, similar to the heart, intracellular synthesis of Ang II and its receptors have been described in the kidney. The renal intracellular RAS and nuclear Ang receptors' signaling mechanisms have recently been reviewed (86-88).

\section{Other tissues or cell types}

Rat VSMCs resemble cardiac myocytes in several aspects, regarding the high glucoseinduced intracellular RAS. Whereas Ang II was primarily localized in the culture medium and was blocked by an ACE inhibitor in normal glucose conditions, high glucose significantly increased intracellular Ang II levels that were primarily the result of vascular chymase-dependent synthesis (8). Corroborating these observations, high glucose significantly decreased ACE expression and knockdown of vascular chymase by siRNA prevented the increase in Ang II levels. Significantly, cathepsin D, not renin, catalyzed the AGT to Ang I conversion in VSMCs (8).

In Capan-1, a human pancreatic cancer derived cell line, high levels of Ang I and Ang II were detected in cells, but not in medium (89). Neither $\mathrm{AT}_{1}$ nor $\mathrm{AT}_{2}$ were detected by RTPCR or immunohistochemistry; however, specific binding to the cell membrane was identified for Ang II. Authors speculated that intracellular Ang II may have a role in pancreatic cancer through non- $\mathrm{AT}_{1}$, non- $\mathrm{AT}_{2}$ binding sites (89).

In the rat sensory vagal complex, $\mathrm{AT}_{1}$ receptor immunoreactivity was observed in endosome-like granules, Golgi lamellae, and outer nuclear membranes, in addition to the plasma membrane (90). These sites also labeled for Ang II, suggesting intracrine effects of Ang II in the modulation of postsynaptic excitability.

Ang II accumulation studies in serum-free culture medium of a bovine aortic endothelial cell line, revealed significant levels in the $2^{\text {nd }} 24$-h period, compared to the first. This was accompanied by undetectable levels of AGT and renin in the medium; but, significant levels intracellularly. The authors concluded that these cells likely synthesized Ang II intracellularly and that it was constitutively secreted (91).

\section{Intracrine Mechanisms: Canonical versus Non-canonical Pathways}

As discussed above, Ang receptors have been localized on several intracellular organelles, particularly nuclei, in multiple cell types that are primary targets of Ang II actions. Although earlier studies had demonstrated direct effects of Ang II on isolated nuclei, recent studies have also begun to identify the involved signaling mechanisms. Essentially, nuclei are 'cells within cells' that contain major signaling pathways. Thus, the signaling pathways activated by Ang II through intracellular $\mathrm{AT}_{1}$ and $\mathrm{AT}_{2}$ receptors, could be classified as canonical pathways. There is also evidence of Ang II actions through novel interactions with intracellular proteins. These non- $\mathrm{AT}_{1}$, non- $\mathrm{AT}_{2}$ mechanisms have been categorized as noncanonical pathways. Our categorization of canonical and non-canonical pathways differs from that described in a recent review on a similar topic, in which the intracrine mechanism of several peptide hormones has been discussed (92). In that review, the authors considered signaling activated by the plasma membrane receptors as canonical and by cognate intracellular receptors as non-canonical pathways. Nonetheless, the knowledge of intracellular mechanisms of intracrine peptides is essential to understand the full repertoire 
of their biological functions. An extensive review of GPCR signaling in the cardiac nucleus was recently published (93).

\section{Canonical pathways}

In rat VSMCs, both intra- and extracellular Ang II activated the cAMP response elementbinding protein (CREB), though by different mechanisms. Extracellular Ang II activated p38MAPK and ERK1/2, whereas intracellular Ang II activated only p38MAPK (38). In studies describing the effects of intracellular Ang II on cytosolic calcium, the production of Ins $(1,4,5,) \mathrm{P} 3$ was identified; whereas cell growth effects required activation of phosphatidyl inositol 3-kinase (PI-3K) and MAPK/ERK $(28,34,35)$. Ang II, applied to renal nuclei isolated from Lewis rats, increased intranuclear reactive oxygen species (ROS) generation, which could be blocked by an ARB or NADPH oxidase (NOX) inhibitor (94). Further, exposure of nuclei to a PKC agonist increased ROS, while a PKC or PI-3K inhibitor abolished the Ang II-induced ROS production, suggesting involvement of an Ang II-AT $1^{-}$ PKC axis at the nuclear level (94). A Mas receptor antagonist and ACE2 inhibitor, exacerbated the Ang II-dependent ROS formation in sheep renal nuclei (85). In isolated nuclei from rat renal cortical cells, Ang II increased transcription of TGF- $\beta 1$, macrophage chemoattractant protein-1, and sodium and hydrogen exchanger-3 in an $\mathrm{AT}_{1}$-dependent manner; however, the molecular signaling pathways were not investigated (95). $\mathrm{AT}_{2}$ receptors on sheep renal cortical nuclei coupled to NO production when stimulated with Ang II (96). Ang II application to nuclei isolated from cardiac myocytes increased NF- $\kappa B$ expression, which appeared to be mediated by both $\mathrm{AT}_{1}$ and $\mathrm{AT}_{2}$ receptors (28). Similar to nuclear receptor, $\mathrm{AT}_{2}$ identified in mitochondria of several cell types modulated mitochondrial NO production and respiration (69). These studies suggested that intracellular Ang II elicits similar signaling pathways and responses as extracellular Ang II, with few exceptions.

\section{Non-canonical pathways}

Non-canonical pathways encompass interaction of Ang II with intracellular proteins other than known Ang receptors, and binding to the nucleolus and chromatin. A possibility of interaction with novel intracellular proteins has been suggested by the observed effects of intracellular Ang II in cells that do not express sufficient levels of $\mathrm{AT}_{1}$ receptor for demonstrable extracellular Ang II effects. These cells include CHO-K1 and A7r5 VSMCs, in which intracellular Ang II effects on cell proliferation and intracellular calcium concentration were not prevented by ARBs $(35,43)$. Direct binding of Ang II to chromatin was demonstrated in some of the early studies of intracrine actions of Ang II $(16,97)$. A direct interaction with chromatin has been reported for other intracrine factors as well (98). Recently, a non- $\mathrm{AT}_{1}$, non- $\mathrm{AT}_{2}$ Ang II binding site in rodent and human brain membranes was identified to be the membrane-bound variant of the metalloendopeptidase, neurolysin (99). The functional significance of high affinity and specific interaction between neurolysin and Ang II remains to be determined. The non-canonical pathways of Ang II deserve future investigation, to more completely elucidate the intracellular RAS.

\section{Conclusion}

The intracellular RAS and intracrine Ang II actions are slowly being accepted as a reality, rather than just a myth. There is a growing body of literature supporting the existence of this system and its role in various pathophysiological conditions (100). Significantly, the intracellular RAS is not confined to a particular tissue; instead there are a number of cell types in different organs which have been shown to have a biologically relevant system. The composition of the intracellular RAS might differ between cell types (9). Further, the activation of this system is likely affected by the pathophysiological state of an organism. 
There remain many unanswered questions, particularly those related to the precise site of intracellular Ang II synthesis, source and mechanism of renin activation in some tissues, and the nature of intracellular receptors and other binding partners. The role of the intracellular system in association with, or independent of the extracellular system, in normal physiological or in pathological states needs to be determined. These studies might lead to new therapeutic avenues for RAS modulation in conditions such as diabetes.

\section{Acknowledgments}

This work was supported by NIH grant 5R01HL090817. This material is the result of work supported with resources and the use of facilities at the Central Texas Veterans Health Care System, Temple, Texas.

\section{References}

1. Tigerstedt R, Bergman P. Niere und Kreislauf. Skand Arch Physiol. 1898; 8:223-271.

2. Dell'italia LJ. Translational success stories: Angiotensin receptor 1 antagonists in heart failure. Circ Res. 2011; 109:437-452. [PubMed: 21817164]

3. Nguyen Dinh Cat A, Touyz RM. Cell signaling of angiotensin II on vascular tone: novel mechanisms. Curr Hypertens Rep. 2011; 13:122-128. [PubMed: 21274755]

4. Marques FD, Ferreira AJ, Sinisterra RD, Jacoby BA, Sousa FB, Caliari MV, Silva GA, Melo MB, Nadu AP, Souza LE, Irigoyen MC, Almeida AP, Santos RA. An oral formulation of angiotensin-(17) produces cardioprotective effects in infarcted and isoproterenol-treated rats. Hypertension. 2011; 57:477-483. [PubMed: 21282558]

5. Stragier B, De Bundel D, Sarre S, Smolders I, Vauquelin G, Dupont A, Michotte Y, Vanderheyden P. Involvement of insulin-regulated aminopeptidase in the effects of the renin-angiotensin fragment angiotensin IV: a review. Heart Fail Rev. 2008; 13:321-337. [PubMed: 17990104]

6. Nguyen G. Renin, (pro)renin and receptor: an update. Clin Sci. 2011; 120:169-178. [PubMed: 21087212]

7. De Mello WC, Frohlich ED. On the local cardiac renin angiotensin system. Basic and clinical implications. Peptides. 2011; 32:1774-1779. [PubMed: 21729730]

8. Lavrentyev EN, Estes AM, Malik KU. Mechanism of high glucose induced angiotensin II production in rat vascular smooth muscle cells. Circ Res. 2007; 101:455-464. [PubMed: 17626897]

9. Kumar R, Boim MA. Diversity of pathways for intracellular angiotensin II synthesis. Curr Opin Nephrol Hypertens. 2009; 18:33-39. [PubMed: 19077687]

10. Kumar, R.; Baker, KM.; Pan, J. Cardiac and Vascular Renin-Angiotensin Systems. In: Carey, RM., editor. Hypertension and Hormone Mechanisms. Humana Press; Totowa, NJ: 2007. p. 23-42.

11. Kumar R, Singh VP, Baker KM. The intracellular renin-angiotensin system: a new paradigm. Trends Endocrinol Metab. 2007; 18:208-214. [PubMed: 17509892]

12. Kumar R, Singh VP, Baker KM. The intracellular renin-angiotensin system in the heart. Curr Hypertens Rep. 2009; 11:104-110. [PubMed: 19278599]

13. Singh VP, Le B, Khode R, Baker KM, Kumar R. Intracellular angiotensin II production in diabetic rats is correlated with cardiomyocyte apoptosis, oxidative stress, and cardiac fibrosis. Diabetes. 2008; 57:3297-3306. [PubMed: 18829990]

14. Singh VP, Le B, Bhat VB, Baker KM, Kumar R. High Glucose Induced Regulation of Intracellular Angiotensin II Synthesis and Nuclear Redistribution in Cardiac Myocytes. Am J Physiol Heart Circ Physiol. 2007; 293:H939-H948. [PubMed: 17483239]

15. Robertson AL Jr, Khairallah PA. Angiotensin II: rapid localization in nuclei of smooth and cardiac muscle. Science. 1971; 172:1138-1139. [PubMed: 4324923]

16. Re RN, Vizard DL, Brown J, Bryan SE. Angiotensin II receptors in chromatin fragments generated by micrococcal nuclease. Biochem Biophys Res Commun. 1984; 119:220-227. [PubMed: 6322777]

17. Re R, Parab M. Effect of angiotensin II on RNA synthesis by isolated nuclei. Life Sci. 1984; 34:647-651. [PubMed: 6199638] 
18. Eggena P, Zhu JH, Clegg K, Barrett JD. Nuclear angiotensin receptors induce transcription of renin and angiotensinogen mRNA. Hypertension. 1993; 22:496-501. [PubMed: 8406654]

19. Booz GW, Conrad KM, Hess AL, Singer HA, Baker KM. Angiotensin-II-binding sites on hepatocyte nuclei. Endocrinology. 1992; 130:3641-3649. [PubMed: 1597161]

20. Tang SS, Rogg H, Schumacher R, Dzau VJ. Characterization of nuclear angiotensin-II-binding sites in rat liver and comparison with plasma membrane receptors. Endocrinology. 1992; 131:374380. [PubMed: 1612017]

21. De Mello WC. Is an intracellular renin-angiotensin system involved in control of cell communication in heart? J Cardiovasc Pharmacol. 1994; 23:640-646. [PubMed: 7516016]

22. De Mello WC. Influence of intracellular renin on heart cell communication. Hypertension. 1995; 25:1172-1177. [PubMed: 7768559]

23. De Mello WC. Further studies on the effect of intracellular angiotensins on heart cell communication: on the role of endogenous angiotensin II. Regul Pept. 2003; 115:31-36. [PubMed: 12873796]

24. De Mello WC, Monterrubio J. Intracellular and extracellular angiotensin II enhance the L-type calcium current in the failing heart. Hypertension. 2004; 44:360-364. [PubMed: 15289467]

25. De Mello WC, Gerena Y. Eplerenone inhibits the intracrine and extracellular actions of angiotensin II on the inward calcium current in the failing heart. On the presence of an intracrine renin angiotensin aldosterone system. Regul Pept. 2008; 151:54-60. [PubMed: 18585409]

26. Baker KM, Chernin MI, Schreiber T, Sanghi S, Haiderzaidi S, Booz GW, Dostal DE, Kumar R. Evidence of a novel intracrine mechanism in angiotensin II-induced cardiac hypertrophy. Regul Pept. 2004; 120:5-13. [PubMed: 15177915]

27. Singh VP, Baker KM, Kumar R. Activation of the Intracellular Renin-Angiotensin System in Cardiac Fibroblasts by High Glucose: Role in Extracellular Matrix Production. Am J Physiol Heart Circ Physiol. 2008; 294:H1675-1684. [PubMed: 18296558]

28. Tadevosyan A, Maguy A, Villeneuve LR, Babin J, Bonnefoy A, Allen BG, Nattel S. Nucleardelimited angiotensin receptor-mediated signaling regulates cardiomyocyte gene expression. J Biol Chem. 2010; 285:22338-22349. [PubMed: 20463030]

29. De Mello WC. Intracellular and extracellular renin have opposite effects on the regulation of heart cell volume. Implications for myocardial ischaemia Journal of the renin-angiotensin-aldosterone system: JRAAS. 2008; 9:112-118.

30. De Mello WC, Gerena Y. Further studies on the effects of intracrine and extracellular angiotensin II on the regulation of heart cell volume. On the influence of aldosterone and spironolactone. Regul Pept. 2010; 165:200-205. [PubMed: 20692299]

31. De Mello WC. Novel aspects of angiotensin II action in the heart. Implications to myocardial ischemia and heart failure. Regul Pept. 2011; 166:9-14. [PubMed: 20934462]

32. Haller H, Lindschau C, Erdmann B, Quass P, Luft FC. Effects of intracellular angiotensin II in vascular smooth muscle cells. Circ Res. 1996; 79:765-772. [PubMed: 8831500]

33. Brailoiu E, Filipeanu CM, Tica A, Toma CP, de Zeeuw D, Nelemans SA. Contractile effects by intracellular angiotensin II via receptors with a distinct pharmacological profile in rat aorta. $\mathrm{Br} \mathbf{J}$ Pharmacol. 1999; 126:1133-1138. [PubMed: 10205000]

34. Filipeanu CM, Henning RH, de Zeeuw D, Nelemans A. Intracellular angiotensin II and cell growth of vascular smooth muscle cells. Br J Pharmacol. 2001; 132:1590-1596. [PubMed: 11264254]

35. Filipeanu CM, Brailoiu E, Kok JW, Henning RH, De Zeeuw D, Nelemans SA. Intracellular angiotensin II elicits Ca2+ increases in A7r5 vascular smooth muscle cells. Eur J Pharmacol. 2001; 420:9-18. [PubMed: 11412834]

36. Filipeanu CM, Brailoiu E, Henning RH, Deelman LE, de Zeeuw D, Nelemans SA. Intracellular angiotensin II inhibits heterologous receptor stimulated Ca2+ entry. Life Sci. 2001; 70:171-180. [PubMed: 11787942]

37. Fierensa FL, Vanderheyden PM, Roggeman C, De Backer J, Thekkumkara TJ, Vauquelin G. Tight binding of the angiotensin AT(1) receptor antagonist. Biochem Pharmacol. 2001; 61:1227-1235. [PubMed: 11322926] 
38. Cook JL, Mills SJ, Naquin R, Alam J, Re RN. Nuclear accumulation of the AT1 receptor in a rat vascular smooth muscle cell line: effects upon signal transduction and cellular proliferation. J Mol Cell Cardiol. 2006; 40:696-707. [PubMed: 16516913]

39. Takao T, Horino T, Kagawa T, Matsumoto R, Shimamura Y, Ogata K, Inoue K, Taniguchi Y, Taguchi T, Morita T, Terada Y. Possible involvement of intracellular angiotensin II receptor in high-glucose-induced damage in renal proximal tubular cells. J Nephrol. 2011; 24:218-224. [PubMed: 20890878]

40. Zhuo JL, Li XC, Garvin JL, Navar LG, Carretero OA. Intracellular angiotensin II induces cytosolic $\mathrm{Ca} 2+$ mobilization by stimulating intracellular AT1 receptors in proximal tubule cells. Am J Physiol Renal Physiol. 2006; 290:F1382-1390. [PubMed: 16380461]

41. Cook JL, Zhang Z, Re RN. In vitro evidence for an intracellular site of angiotensin action. Circ Res. 2001; 89:1138-1146. [PubMed: 11739278]

42. Cook JL, Re R, Alam J, Hart M, Zhang Z. Intracellular angiotensin II fusion protein alters AT1 receptor fusion protein distribution and activates CREB. J Mol Cell Cardiol. 2004; 36:75-90. [PubMed: 14734050]

43. Baker KM, Kumar R. Intracellular Angiotensin II Induces Cell Proliferation Independent of AT1 Receptor. Am J Physiol Cell Physiol. 2006; 291:C995-1001. [PubMed: 16774988]

44. Pepperell JR, Nemeth G, Yamada Y, Naftolin F, Merino M. Localized accumulation of angiotensin II and production of angiotensin-(1-7) in rat luteal cells and effects on steroidogenesis. Am J Physiol Endocrinol Metab. 2006; 291:E221-233. [PubMed: 16478781]

45. Frustaci A, Kajstura J, Chimenti C, Jakoniuk I, Leri A, Maseri A, Nadal-Ginard B, Anversa P. Myocardial cell death in human diabetes. Circ Res. 2000; 87:1123-1132. [PubMed: 11110769]

46. Redding KM, Chen BL, Singh A, Re RN, Navar LG, Seth DM, Sigmund CD, Tang WW, Cook JL. Transgenic mice expressing an intracellular fluorescent fusion of angiotensin II demonstrate renal thrombotic microangiopathy and elevated blood pressure. Am J Physiol Heart Circ Physiol. 2010; 298:H1807-1818. [PubMed: 20363893]

47. Li XC, Cook JL, Rubera I, Tauc M, Zhang F, Zhuo JL. Intrarenal transfer of an intracellular fluorescent fusion of angiotensin II selectively in proximal tubules increases blood pressure in rats and mice. Am J Physiol Renal Physiol. 2011; 300:F1076-1088. [PubMed: 21307128]

48. Basso N, Terragno NA. History about the discovery of the renin-angiotensin system. Hypertension. 2001; 38:1246-1249. [PubMed: 11751697]

49. Hunt MK, Ramos SP, Geary KM, Norling LL, Peach MJ, Gomez RA, Carey RM. Colocalization and release of angiotensin and renin in renal cortical cells. Am J Physiol. 1992; 263:F363-373. [PubMed: 1415565]

50. Mercure C, Ramla D, Garcia R, Thibault G, Deschepper CF, Reudelhuber TL. Evidence for intracellular generation of angiotensin II in rat juxtaglomerular cells. FEBS Lett. 1998; 422:395399. [PubMed: 9498824]

51. Inagami T, Kawamura M, Naruse K, Okamura T. Localization of components of the reninangiotensin system within the kidney. Fed Proc. 1986; 45:1414-1419. [PubMed: 3514278]

52. Vila-Porcile E, Corvol P. Angiotensinogen, prorenin, and renin are Co-localized in the secretory granules of all glandular cells of the rat anterior pituitary: an immunoultrastructural study. $\mathrm{J}$ Histochem Cytochem. 1998; 46:301-311. [PubMed: 9487111]

53. Sadoshima J, Xu Y, Slayter HS, Izumo S. Autocrine release of angiotensin II mediates stretchinduced hypertrophy of cardiac myocytes in vitro. Cell. 1993; 75:977-984. [PubMed: 8252633]

54. Fischer TA, Ungureanu-Longrois D, Singh K, de Zengotita J, DeUgarte D, Alali A, Gadbut AP, Lee MA, Balligand JL, Kifor I, Smith TW, Kelly RA. Regulation of bFGF expression and ANG II secretion in cardiac myocytes and microvascular endothelial cells. Am J Physiol. 1997; 272:H958968. [PubMed: 9124460]

55. Sherrod M, Liu X, Zhang X, Sigmund CD. Nuclear localization of angiotensinogen in astrocytes. Am J Physiol Regul Integr Comp Physiol. 2004; 288:R539-546. [PubMed: 15388495]

56. Peters J. Secretory and cytosolic (pro)renin in kidney, heart, and adrenal gland. J Mol Med. 2008; 86:711-714. [PubMed: 18368380]

57. Sinn PL, Sigmund CD. Identification of three human renin mRNA isoforms from alternative tissue-specific transcriptional initiation. Physiol Genomics. 2000; 3:25-31. [PubMed: 11015597] 
58. Lee-Kirsch MA, Gaudet F, Cardoso MC, Lindpaintner K. Distinct renin isoforms generated by tissue-specific transcription initiation and alternative splicing. Circ Res. 1999; 84:240-246. [PubMed: 9933256]

59. Clausmeyer S, Reinecke A, Farrenkopf R, Unger T, Peters J. Tissue-specific expression of a rat renin transcript lacking the coding sequence for the prefragment and its stimulation by myocardial infarction. Endocrinology. 2000; 141:2963-2970. [PubMed: 10919285]

60. Peters J, Wanka H, Peters B, Hoffmann S. A renin transcript lacking exon 1 encodes for a nonsecretory intracellular renin that increases aldosterone production in transgenic rats. J Cell Mol Med. 2008; 12:1229-1237. [PubMed: 18782187]

61. Lavoie JL, Liu X, Bianco RA, Beltz TG, Johnson AK, Sigmund CD. Evidence supporting a functional role for intracellular renin in the brain. Hypertension. 2006; 47:461-466. [PubMed: 16446393]

62. Wanka H, Kessler N, Ellmer J, Endlich N, Peters BS, Clausmeyer S, Peters J. Cytosolic renin is targeted to mitochondria and induces apoptosis in $\mathrm{H} 9 \mathrm{c} 2$ rat cardiomyoblasts. J Cell Mol Med. 2009; 13:2926-2937. [PubMed: 18671756]

63. Camargo de Andrade MC, Di Marco GS, de Paulo Castro Teixeira V, Mortara RA, Sabatini RA, Pesquero JB, Boim MA, Carmona AK, Schor N, Casarini DE. Expression and localization of Ndomain ANG I-converting enzymes in mesangial cells in culture from spontaneously hypertensive rats. Am J Physiol Renal Physiol. 2006; 290:F364-375. [PubMed: 16106038]

64. Lucero HA, Kintsurashvili E, Marketou ME, Gavras H. Cell signaling, internalization, and nuclear localization of the angiotensin converting enzyme in smooth muscle and endothelial cells. J Biol Chem. 2010; 285:5555-5568. [PubMed: 20022959]

65. Endo-Mochizuki Y, Mochizuki N, Sawa H, Takada A, Okamoto H, Kawaguchi H, Nagashima K, Kitabatake A. Expression of renin and angiotensin-converting enzyme in human hearts. Heart Vessels. 1995; 10:285-293. [PubMed: 8655465]

66. Pieruzzi F, Abassi ZA, Keiser HR. Expression of renin-angiotensin system components in the heart, kidneys, and lungs of rats with experimental heart failure. Circulation. 1995; 92:3105-3112. [PubMed: 7586282]

67. Muller DN, Fischli W, Clozel JP, Hilgers KF, Bohlender J, Menard J, Busjahn A, Ganten D, Luft FC. Local angiotensin II generation in the rat heart: role of renin uptake. Circ Res. 1998; 82:1320. [PubMed: 9440700]

68. Kumar R, Yong QC, Thomas CM, Baker KM. Review: Intracardiac intracellular angiotensin system in diabetes. Am J Physiol Regul Integr Comp Physiol. 2012; 302:R510-517. [PubMed: 22170614]

69. Abadir PM, Foster DB, Crow M, Cooke CA, Rucker JJ, Jain A, Smith BJ, Burks TN, Cohn RD, Fedarko NS, Carey RM, O’Rourke B, Walston JD. Identification and characterization of a functional mitochondrial angiotensin system. Proc Natl Acad Sci U S A. 2011; 108:14849-14854. [PubMed: 21852574]

70. Bkaily G, Sleiman S, Stephan J, Asselin C, Choufani S, Kamal M, Jacques D, Gobeil F Jr, D’Orleans-Juste P. Angiotensin II AT1 receptor internalization, translocation and de novo synthesis modulate cytosolic and nuclear calcium in human vascular smooth muscle cells. Can $\mathbf{J}$ Physiol Pharmacol. 2003; 81:274-287. [PubMed: 12733826]

71. Lee DK, Lanca AJ, Cheng R, Nguyen T, Ji XD, Gobeil F Jr, Chemtob S, George SR, O’Dowd BF. Agonist-Independent nuclear localization of the apelin, angiotensin AT1 and bradykinin B2 receptors. J Biol Chem. 2003; 279:7901-7908. [PubMed: 14645236]

72. Senbonmatsu T, Saito T, Landon EJ, Watanabe O, Price E Jr, Roberts RL, Imboden H, Fitzgerald TG, Gaffney FA, Inagami T. A novel angiotensin II type 2 receptor signaling pathway: possible role in cardiac hypertrophy. The EMBO journal. 2003; 22:6471-6482. [PubMed: 14657020]

73. Cristovam PC, Arnoni CP, de Andrade MC, Casarini DE, Pereira LG, Schor N, Boim MA. ACEand chymase-dependent angiotensin II generation in normal and glucose-stimulated human mesangial cells. Exp Biol Med (Maywood). 2008; 233:1035-1043. [PubMed: 18480420]

74. Leite CA, Cristovam PC, Leitao AA, Miranda A, Andrade MC, Di Marco G, Casarini DE, Boim MA. Renin similar to the submaxillary gland form is expressed in mouse mesangial cells: 
subcellular localization and all generation under control and glucose-stimulated conditions. Cell Physiol Biochem. 2003; 13:357-366. [PubMed: 14631142]

75. Vidotti DB, Casarini DE, Cristovam PC, Leite CA, Schor N, Boim MA. High glucose concentration stimulates intracellular renin activity and angiotensin II generation in rat mesangial cells. Am J Physiol Renal Physiol. 2004; 286:F1039-1045. [PubMed: 14722017]

76. Singh R, Leehey DJ. Effect of ACE inhibitors on angiotensin II in rat mesangial cells cultured in high glucose. Biochem Biophys Res Commun. 2007; 357:1040-1045. [PubMed: 17466950]

77. Huang XR, Chen WY, Truong LD, Lan HY. Chymase is upregulated in diabetic nephropathy: implications for an alternative pathway of angiotensin II-mediated diabetic renal and vascular disease. J Am Soc Nephrol. 2003; 14:1738-1747. [PubMed: 12819233]

78. Sakoda M, Ichihara A, Kurauchi-Mito A, Narita T, Kinouchi K, Murohashi-Bokuda K, Saleem MA, Nishiyama A, Suzuki F, Itoh H. Aliskiren Inhibits Intracellular Angiotensin II Levels Without Affecting (Pro)renin Receptor Signals in Human Podocytes. Am J Hypertens. 2010; 23:575-580. [PubMed: 20075844]

79. Ichihara A, Sakoda M, Kurauchi-Mito A, Kaneshiro Y, Itoh H. Renin, prorenin and the kidney: a new chapter in an old saga. J Nephrol. 2009; 22:306-311. [PubMed: 19557706]

80. Huang J, Matavelli LC, Siragy HM. Renal (pro)renin receptor contributes to development of diabetic kidney disease through transforming growth factor-beta1-connective tissue growth factor signalling cascade. Clin Exp Pharmacol Physiol. 2011; 38:215-221. [PubMed: 21265872]

81. Cheng H, Fan X, Moeckel GW, Harris RC. Podocyte COX-2 exacerbates diabetic nephropathy by increasing podocyte (pro)renin receptor expression. J Am Soc Nephrol. 2011; 22:1240-1251. [PubMed: 21737546]

82. Durvasula RV, Shankland SJ. Activation of a local renin angiotensin system in podocytes by glucose. Am J Physiol Renal Physiol. 2008; 294:F830-839. [PubMed: 18216149]

83. Yoo TH, Li JJ, Kim JJ, Jung DS, Kwak SJ, Ryu DR, Choi HY, Kim JS, Kim HJ, Han SH, Lee JE, Han DS, Kang SW. Activation of the renin-angiotensin system within podocytes in diabetes. Kidney Int. 2007; 71:1019-1027. [PubMed: 17361112]

84. Pendergrass KD, Averill DB, Ferrario CM, Diz DI, Chappell MC. Differential expression of nuclear AT1 receptors and angiotensin II within the kidney of the male congenic mRen2.Lewis rat. Am J Physiol Renal Physiol. 2006; 290:F1497-1506. [PubMed: 16403834]

85. Gwathmey TM, Pendergrass KD, Reid SD, Rose JC, Diz DI, Chappell MC. Angiotensin-(1-7)angiotensin-converting enzyme 2 attenuates reactive oxygen species formation to angiotensin II within the cell nucleus. Hypertension. 2010; 55:166-171. [PubMed: 19948986]

86. Ellis B, Li XC, Miguel-Qin E, Gu V, Zhuo JL. Review: Evidence for a Functional Intracellular Angiotensin System in the Proximal Tubule of the Kidney. Am J Physiol Regul Integr Comp Physiol. 2012; 302:R494-509. [PubMed: 22170616]

87. Gwathmey TM, Alzayadneh EM, Pendergrass KD, Chappell MC. Review: Novel roles of nuclear angiotensin receptors and signaling mechanisms. Am J Physiol Regul Integr Comp Physiol. 2012; 302:R518-530. [PubMed: 22170620]

88. Cook JL, Re RN. Review: Lessons from in vitro studies and a related intracellular angiotensin II transgenic mouse model. Am J Physiol Regul Integr Comp Physiol. 2012; 302:R482-493. [PubMed: 22170617]

89. Pérez-Díaz I, Guzmán C, Olivares-Reyes JA, Ramírez T, Gutierréz-Reyes G, Hiriart M, RoblesDíaz G. Evidence of an Intracellular Angiotensin-Generating System and Non-AT1, Non-AT2 Binding Site in a Human Pancreatic Cell Line. Pancreas. 2011; 40:701-707. [PubMed: 21602736]

90. Huang J, Hara Y, Anrather J, Speth RC, Iadecola C, Pickel VM. Angiotensin II subtype 1A (AT1A) receptors in the rat sensory vagal complex: subcellular localization and association with endogenous angiotensin. Neuroscience. 2003; 122:21-36. [PubMed: 14596846]

91. Kifor I, Dzau VJ. Endothelial renin-angiotensin pathway: evidence for intracellular synthesis and secretion of angiotensins. Circ Res. 1987; 60:422-428. [PubMed: 3555883]

92. Re RN, Cook JL. Noncanonical intracrine action. 2011; 5:435-448.

93. Tadevosyan A, Vaniotis G, Allen BG, Hebert TE, Nattel S. G protein-coupled receptor signalling in the cardiac nuclear membrane: evidence and possible roles in physiological and pathophysiological function. J Physiol. 2012; 590:1313-1330. [PubMed: 22183719] 
94. Pendergrass KD, Gwathmey TM, Michalek RD, Grayson JM, Chappell MC. The angiotensin IIAT1 receptor stimulates reactive oxygen species within the cell nucleus. Biochem Biophys Res Commun. 2009; 384:149-154. [PubMed: 19409874]

95. Li XC, Zhuo JL. Intracellular ANG II directly induces in vitro transcription of TGF-beta1, MCP-1, and NHE-3 mRNAs in isolated rat renal cortical nuclei via activation of nuclear AT1a receptors. Am J Physiol Cell Physiol. 2008; 294:C1034-1045. [PubMed: 18256274]

96. Gwathmey TM, Shaltout HA, Pendergrass KD, Pirro NT, Figueroa JP, Rose JC, Diz DI, Chappell MC. Nuclear angiotensin II type 2 (AT2) receptors are functionally linked to nitric oxide production. Am J Physiol Renal Physiol. 2009; 296:F1484-1493. [PubMed: 19244399]

97. Erdmann B, Fuxe K, Ganten D. Subcellular localization of angiotensin II immunoreactivity in the rat cerebellar cortex. Hypertension. 1996; 28:818-824. [PubMed: 8901829]

98. Rakowicz-Szulczynska EM, Rodeck U, Herlyn M, Koprowski H. Chromatin binding of epidermal growth factor, nerve growth factor, and platelet-derived growth factor in cells bearing the appropriate surface receptors. Proc Natl Acad Sci U S A. 1986; 83:3728-3732. [PubMed: 3012531]

99. Wangler NJ, Santos KL, Schadock I, Hagen FK, Escher E, Bader M, Speth RC, Karamyan VT. Identification of membrane-bound variant of metalloendopeptidase neurolysin (EC 3.4.24.16) as the non-AT1, non-AT2 angiotensin binding site. J Biol Chem. 2011; 287:114-122. [PubMed: 22039052]

100. Kumar R, Singh VP, Baker KM. The Intracellular Renin-Angiotensin System - Implications in Cardiovascular Remodeling. Curr Opin Nephrol Hypertens. 2008; 17:168-173. [PubMed: 18277150] 


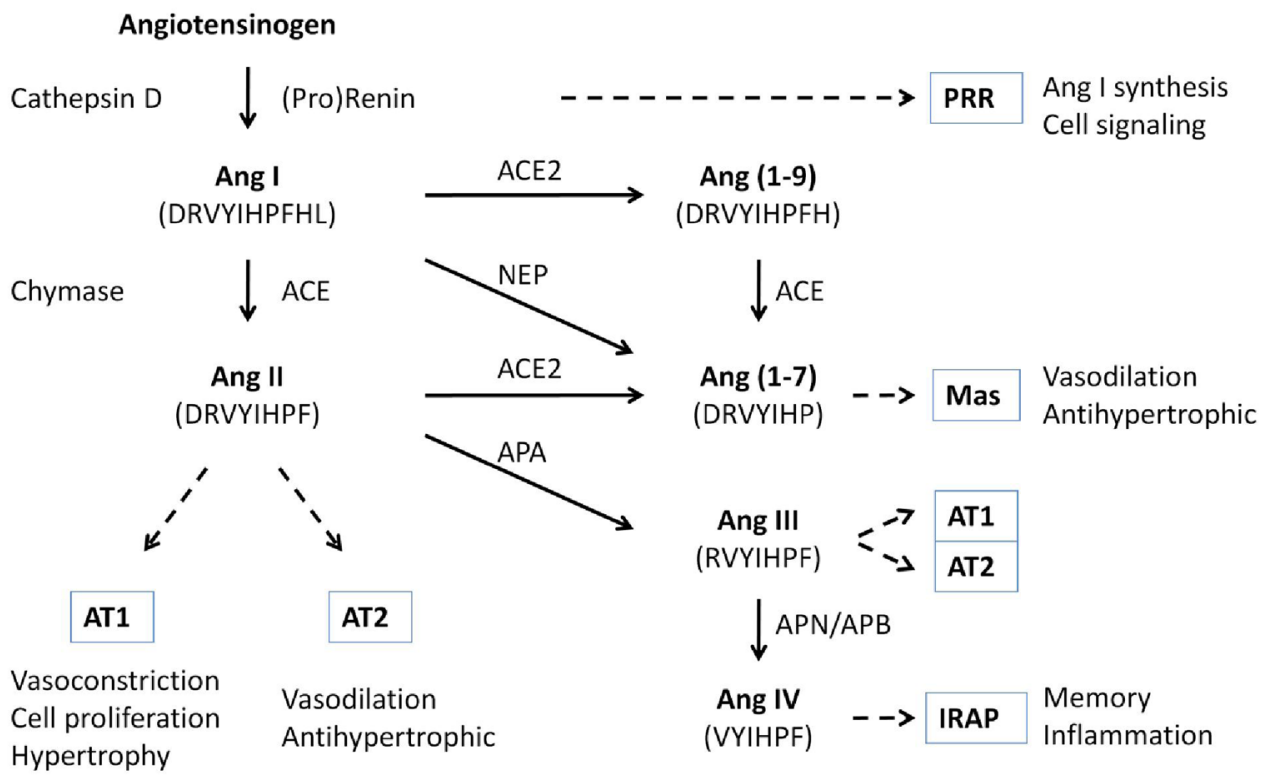

Classical RAS

Novel RAS

Figure 1. The classical and the novel RAS

The classical RAS has Ang II as the bioactive peptide, which is formed from AGT, by the actions of renin and ACE. In some tissues or pathophysiological states, alternative enzymes such as cathepsin D and chymase may be utilized. Ang II acts through AT1 and AT2 receptors, which have opposite biological effects. The novel RAS consists of fragments of Ang II formed by the action of different peptidases. Three peptides, Ang 1-7, Ang III, and Ang IV, have been shown to have significant biological activity. (Pro)renin, which cleaves AGT to Ang I, has been shown to bind the (pro)renin receptor and activate intracellular signaling events. ACE, angiotensin converting enzyme; ACE2, angiotensin converting enzyme 2; APA, aminopeptidase A; APB, aminopeptidase B; APN, aminopeptidase N; IRAP, insulin-regulated aminopeptidase; NEP, neutral endopeptidase; PRR, (pro)renin receptor. 


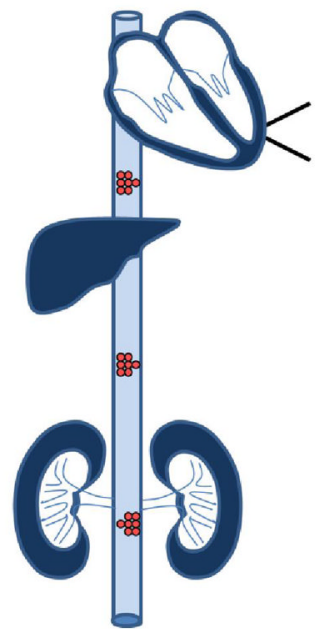

Circulating

RAS

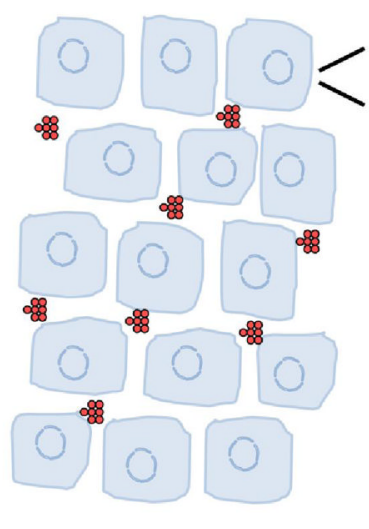

Tissue

RAS

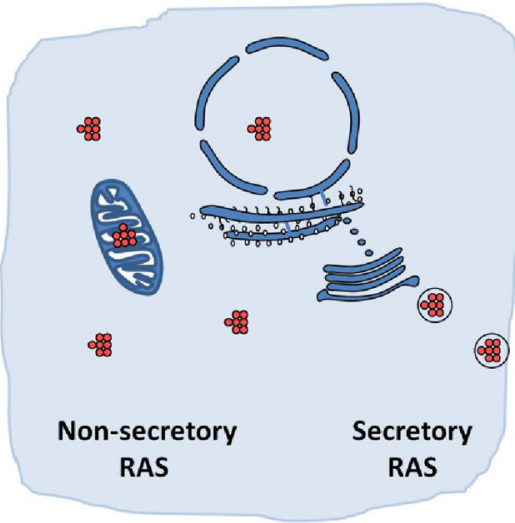

Intracellular

RAS

Figure 2. The circulating, tissue, and intracellular RASs

Based on the site of Ang II generation (denoted as red dots), the RAS can be classified as the circulating, tissue, or the intracellular RAS. In the circulating RAS, Ang II is formed in the blood from AGT secreted by liver, by the actions of renin secreted from kidneys and ACE present on vascular endothelial cells. The circulating RAS represents an endocrine system. In the tissue RAS, Ang II synthesis occurs in the interstitial space from components largely produced in the same tissue. The tissue Ang II acts locally in an autocrine/paracrine manner. The intracellular RAS is defined by Ang II synthesis inside the cell, either in secretory vesicles (the secretory RAS) or in other cellular regions or organelles (the non-secretory RAS). Intracellular Ang II has been localized in the cytoplasm, mitochondria, and nuclei. Mitochondria and nuclei have also been demonstrated to contain angiotensin receptors. Ang II actions arising from an intracellular location are termed intracrine actions. 